\title{
Management of bacterial severe sepsis and septic shock
}

\author{
Kathleen Chiotos ${ }^{\mathrm{a}, \mathrm{b}}$, Fran Balamuth ${ }^{\mathrm{c}, \mathrm{d}}$ and Halden F. Scott ${ }^{\mathrm{e}, \mathrm{f}, *}$ \\ a Division of Critical Care, The Children's Hospital of Philadelphia, Philadelphia, PA, USA \\ ${ }^{\mathrm{b}}$ Division of Infectious Diseases, The Children's Hospital of Philadelphia, Philadelphia, PA, USA \\ ${ }^{\mathrm{c}}$ Department of Pediatrics, University of Pennsylvania Perelman School of Medicine, Philadelphia, PA, USA \\ ${ }^{\mathrm{d} D i v i s i o n}$ of Emergency Medicine and Center for Pediatric Clinical Effectiveness, Children's Hospital \\ of Philadelphia, Philadelphia, PA, USA \\ ${ }^{\mathrm{e}}$ Department of Pediatrics, University of Colorado School of Medicine, Aurora, CO, USA \\ ${ }^{\mathrm{f}}$ Section of Emergency Medicine, Children's Hospital Colorado, Aurora, CO, USA
}

Received 15 July 2014

Revised 3 October 2014

Accepted 7 October 2014

\begin{abstract}
Bacterial sepsis is a leading cause of pediatric morbidity and mortality worldwide. Early diagnosis, a coordinated and aggressive approach to initial resuscitation, and timely and appropriate antibiotic therapy are paramount to improving outcomes of these dangerous infections. The basic tenants of initial and ongoing resuscitation include rapid isotonic intravenous fluid boluses with reassessment for physiologic response, empiric broad-spectrum antibiotics directed to cover suspected sources of infection, source control, vasoactive infusions, supportive critical care and monitoring of response to therapy. In addition to resuscitation of bacterial sepsis, this article will review approaches to empiric antibiotic choice in septic shock, and detail definitive management of infections caused by several specific organisms, including Staphylococcus aureus, group A Streptococcus, Pseudomonas aeruginosa, Mycobacterium tuberculosis, and Clostridium difficile. Lastly, management of several common pediatric infections, including community acquired bacterial pneumonia and bacterial meningitis, will be reviewed.
\end{abstract}

Keywords: Anti-bacterial agents, bacteremia, pediatric, resuscitation, septic shock, sepsis

\section{Introduction}

Infectious diseases are the leading cause of death in children younger than 5-year-old worldwide, accounting for over $50 \%$ of deaths (approximately 3.26 million children). The most common etiologies include pneumonia (15\%), diarrheal illness $(9 \%)$, malaria $(7 \%)$, pertussis, human immunodeficiency virus, meningitis,

\footnotetext{
*Corresponding author: Halden F. Scott, MD, University of Colorado School of Medicine, Department of Pediatrics, 13123 East 16th Ave, B251, Aurora, CO 80045, USA. Tel.: +1 303724 2601; E-mail: halden.scott@childrenscolorado.org.
}

and measles [1]. In the United States (US), there are approximately 75.000 cases of pediatric severe sepsis requiring hospitalization annually [2]. Estimates of mortality among children hospitalized with sepsis vary. In the last decade, in-hospital pediatric sepsis mortality has been estimated at $19 \%$ in Brazil, $4.2 \%-21.2 \%$ in the US, and $1-2 \%$ in hospitals with sepsis treatment protocols in the United Kingdom and Netherlands [2-8]. A large international point prevalence study investigating sepsis prevalence, outcomes, and therapies is currently underway at 127 institutions in 27 countries, and will further characterize the epidemiology of pediatric sepsis. 
Several factors influence the potential pathogens causing pediatric sepsis, including hospital versus community onset, age, host immune status, underlying illness, and presence of a central venous catheter. In the US, the most common identified bacterial causes of sepsis include Staphylococcus species (including coagulase negative Staphylococcus and Staphylococcus aureus), Streptococcus species (including Streptococcus pneumoniae, group A Streptococcus and group B Streptococcus), Pseudomonas species, and Escherichia coli [2]. In Europe, Neisseria meningitidis is also a frequent cause of bacterial sepsis. In African children with bacteremia, the most common pathogens are S. pneumonia, Salmonella typhi, Haemophilus influenza, and E. coli [9]. Hospitalacquired and central-line associated bacteremia are also an important cause of bacterial sepsis in both high and low-income countries [10,11].

\section{Pathophysiology and clinical presentation}

In septic shock, bacterial infection progresses to circulatory dysfunction, organ dysfunction and shock by triggering an inflammatory host response. Some bacterial toxins directly cause inflammatory and circulatory changes, and in many cases, it is the interaction between bacteria and the host immune response that triggers the pathophysiologic inflammatory cascade. Lipopolysaccharide (endotoxin) is a component of the cell membrane of Gram-negative bacteria, which triggers an inflammatory response in the host, specifically tumor necrosis factor alpha and interleukin 1 . This launches a cascade of cytokines promoting fever, leukocytosis, procoagulant effects, and increased vascular permeability $[12,13]$.

Deleterious consequences include endothelial cell damage, capillary leak, microcirculatory shutdown and resultant hypovolemic shock with decreased tissue oxygenation and mitochondrial dysfunction. The inflammatory immune response also causes vasodilation, myocardial depression, activation of the complement system, disseminated intravascular coagulation and increased production of nitric oxide. Unchecked, this inflammatory cascade progresses to end-organ hypoperfusion and multisystem organ failure $[14,15]$.

Decompensated shock represents an advanced shock state in which hypotension is present. Early signs of shock include alterations in mental status and perfusion, and diminished urine output. In cold shock, characterized by decreased myocardial contractility and peripheral vasoconstriction, signs include cold, mottled extremities, delayed capillary refill time, and weak, thready pulses. Warm shock, characterized by vasodilation, presents with warm, flushed skin, rapid ('flash') capillary refill time and bounding pulses. Some bacterial infections are characterized by petechial or purpuric rashes, which are signs of capillary fragility or disseminated intravascular coagulation and platelet consumption, but these features are not exclusive to bacterial disease.

\section{Resuscitation in bacterial sepsis}

The pillars of early treatment of bacterial sepsis are rapid and timely establishment of intravascular access, administration of fluid boluses, and administration of appropriate, broad-spectrum antibiotics. Treatment of hypoxia, hypoglycemia, and hypocalcemia should also occur [16].

\subsection{Fluid resuscitation}

Fluid resuscitation should be directed to improve signs of poor perfusion and hypotension, and patients should be monitored for signs of fluid overload. Multiple studies have demonstrated improved septic shock survival in adults with quantitative resuscitation aimed at reversing shock, though the method by which successful resuscitation is measured continues to be debated [17-20]. The recently completed Protocol-Based Care for Early Septic Shock (ProCESS) trial indicated no differences in outcomes whether shock reversal was measured by central venous pressure/venous oxygen saturation or hypotension/shock index/ clinical exam [21]. Retrospective pediatric studies have also demonstrated improved survival with timely fluid resuscitation, though large-scale prospective studies of fluid resuscitation and bundled sepsis care in pediatrics have not yet been performed in the US [22].

The safety and efficacy of fluid resuscitation in pediatric sepsis in Sub-Saharan Africa has been called into question by the Fluid Expansion as Supportive Therapy (FEAST) trial by Maitland et al. [23]. This large prospective randomized controlled trial demonstrated increased mortality in children with severe infection who received 20 or $40 \mathrm{~mL} / \mathrm{kg}$ of fluid resuscitation in the first hour compared to those who received none. These results may be specific to the local host 
population with high prevalence of malaria and low availability of critical care interventions, and may not extend to hypotensive septic shock, which comprised only $1 \%$ of the study population [23-25].

\subsection{Vasoactive agents}

Continued shock after administration of $60 \mathrm{~mL} / \mathrm{kg}$ of isotonic fluid bolus should be treated with vasoactive agents. Dopamine is the recommended first-line agent in children, though recent data suggest increased mortality in adult patients treated for shock with dopamine. Some clinicians therefore prefer to avoid dopamine in children and begin with norepinephrine or epinephrine, but there is a paucity of pediatric data to inform this strategy and guidelines continue to recommend the use of dopamine as first line therapy in children. Choice of vasoactive depends on assessment of cardiac output and systemic vascular resistance. Cold shock, which is characterized by a low cardiac output and increased systemic vascular resistance, is best managed with inotropes, including dobutamine or epinephrine. Warm shock, which is characterized by normal or high cardiac output and decreased systemic vascular resistance, is best managed with norepinephrine [16]. Specific choice of agent should be dictated by ongoing assessment of an individual patient's pathophysiology and response, which may be affected by nitric oxide and hepatic and renal clearance of the agent. In addition to clinical exam, assessment of cardiovascular hemodynamics and choice of vasoactive agents can be enhanced by use of bedside echocardiography and invasive and noninvasive cardiac output monitors [16, 26].

\subsection{Timely and appropriate antibiotics}

The Surviving Sepsis Campaign recommends antibiotic administration within one hour of recognition of septic shock [27]. In critically ill adults with sepsis, evidence suggests that delays in appropriate antimicrobial therapy increase mortality [28-31]. Recent data also demonstrates that delays over three $\mathrm{hr}$ in antibiotic administration are associated with increased mortality and more prolonged organ dysfunction in pediatric patients with severe sepsis or septic shock [32]. In addition, these studies demonstrate the importance of appropriate antibiotic selection in improving sepsis outcomes [30, 33]. Institutional antibiograms can help to facilitate antibiotic selection in sepsis, and are typically based on host factors, suspected source, and local microbial susceptibility patterns [34]. Examples of institutional antibiotic recommendations are shown in Figs. 1 and 2.

\subsection{Source control}

In cases where a reservoir or focal source of infection exists, the principle of early "source control" is essential to successful containment of the infection and inflammatory cascade. Systemic antibiotics, even if optimized, will not effectively penetrate focal abscesses, pus, or infections associated with foreign bodies or central lines, which can continue to seed infection if not drained or removed. Abscess drainage should be considered initially and in patients failing to improve despite appropriate intravenous therapy.

\subsection{Impact of protocol-based sepsis care}

Timely sepsis care has been identified as a quality metric at many pediatric institutions in the US and Europe. Several pediatric institutions have successfully implemented protocol-based sepsis care and have demonstrated associated improvements in the delivery of timely sepsis care $[6,35-38]$. These improvements have been associated with decreased intensive care unit (ICU) and hospital length of stay, and a mortality reduction has been demonstrated in meningococcemia $[6,37]$.

\section{Specific pathogens}

While the range of organisms causing bacteremia in children is extensive, the most common and significant pathogens will be discussed below.

\subsection{S. aureus}

S. aureus bacteremia should always prompt a careful evaluation for both source of bacteremia and presence of metastatic complications [39]. The most common sources of $S$. aureus bacteremia in children include skin and soft infections, musculoskeletal infections, endovascular infections, including central line associated bloodstream infections, and bacteremia without a focus [40, 41]. Metastatic complications can include infective endocarditis, vertebral and nonvertebral osteomyelitis, and pulmonary infiltrates [42]. Current Infectious Diseases Society of America guidelines recommend echocardiography in adult patients 


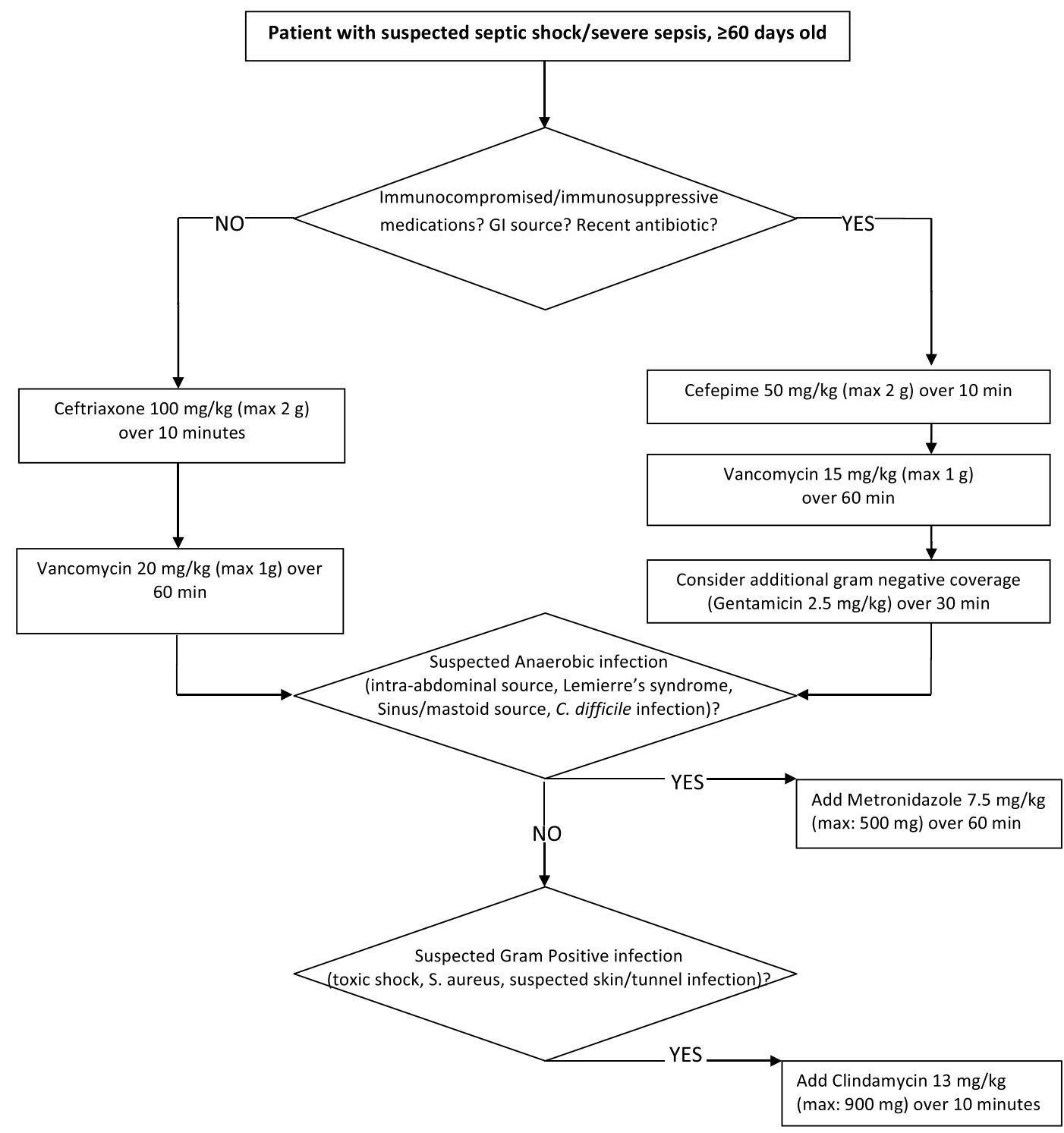

Additional Considerations:

- Check prior + cultures. For patients with history of resistant pathogens, add coverage based on historic susceptibilities.

- Vancomycin should be dosed at $15 \mathrm{mg} / \mathrm{kg}$ for all oncology patients. Do NOT add Clinda without consulting with oncology.

- For patients on broad-spectrum antimicrobials, consider yeast coverage.

- For patients with suspected meningitis, consider dexamethasone immediately before or shortly after first antibiotic dose.

- Consider ID consultation for allergies, history of resistance, yeast coverage or other complicating factors. Primary service should be consulted as soon as feasible for all severe sepsis/septic shock.

Fig. 1. Children's Hospital Colorado antibiotic recommendations for patients with severe sepsis/septic shock (Children's Hospital Colorado Sepsis Antibiotic Recommendations, printed with permission from its authors, Sarah K. Parker and Jason Child). GI=Gastrointestinal; $\mathrm{ID}=$ Infectious diseases. 

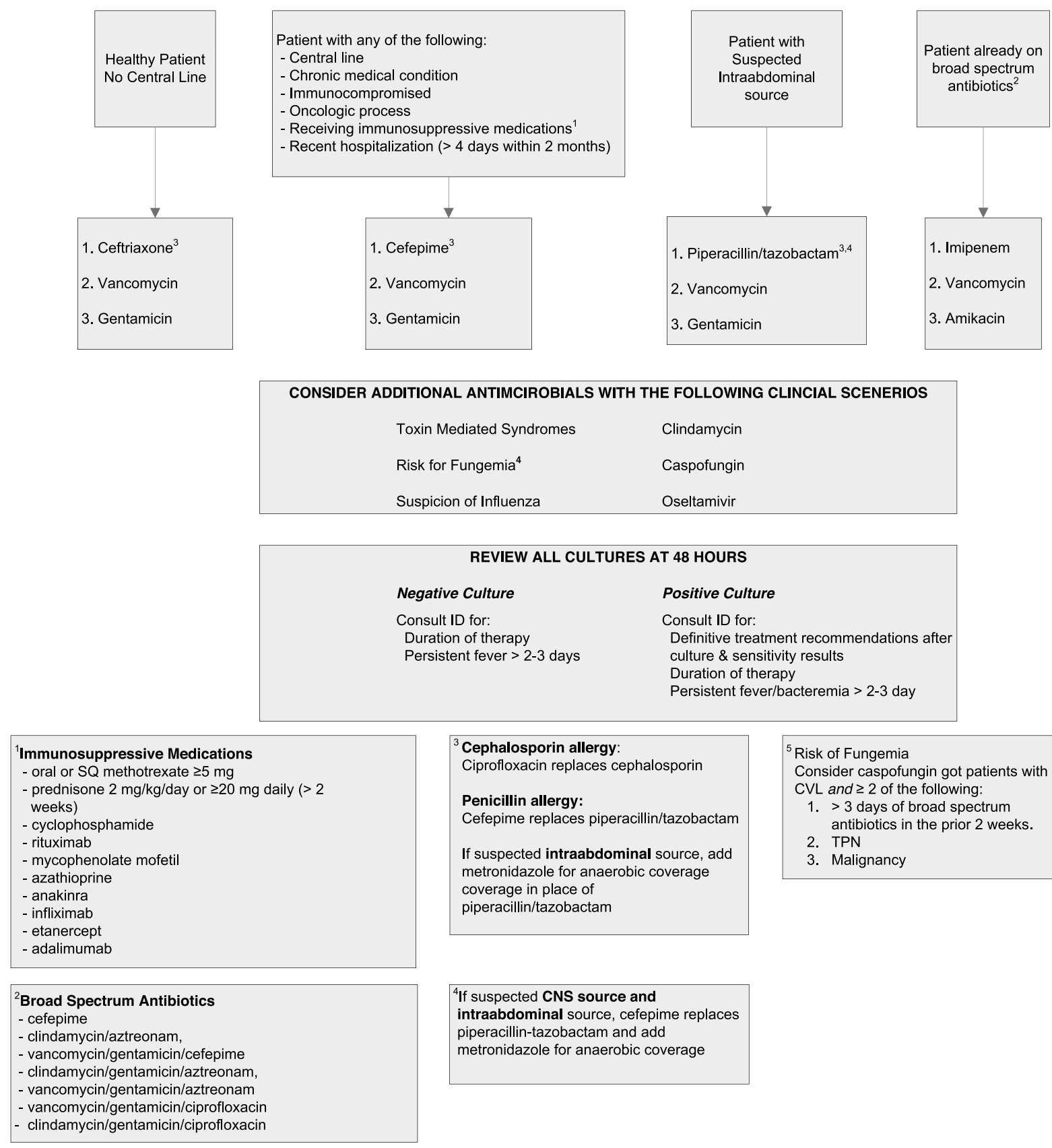

Fig. 2. Children's Hospital of Philadelphia antibiotic recommendations for patients with severe sepsis/septic shock (The Children's Hospital of Philadelphia 2014. Available at: http://www.chop.edu/clinical-pathway/severe-sepsisseptic-shock-icu-clinical-pathway-infants-28-days-andchildren-3. Accessed November 10, 2014). ID = Infectious diseases; SQ = Subcutaneous; $C V L=C e n t r a l$ venous line; TPN $=$ Total parenteral nutrition; CNS = Central nervous system.

with $S$. aureus bacteremia, but this can generally be avoided in children unless they have congenital heart disease, clinical signs of endocarditis, or bacteremia exceeding $72 \mathrm{hr}$ in duration, as previously healthy children with short-lived bacteremia are at low risk for this complication [39, 43]. 
Empiric therapy for $S$. aureus bacteremia should include coverage for both methicillin-sensitive organisms as well as methicillin-resistant organisms, such as vancomycin combined with a beta-lactam antibiotic [42]. The reason for this is the well-documented superiority of beta-lactams over vancomycin for methicillin-susceptible $S$. aureus [44-47]. Once the susceptibility pattern of $S$. aureus is known, therapy should be narrowed accordingly. For methicillin-susceptible isolates, the semi-synthetic anti-staphylococcal penicillins, including nafcillin, oxacillin, or methicillin, are the traditional drugs of choice, though cefazolin has been shown to be equally efficacious and its easier dosing schedule and tolerability make it an appealing alternative [45]. Other cephalosporins may be less efficacious in treating methicillin-susceptible $S$. aureus bacteremia, though ceftriaxone appears to be equally effective in treating osteoarticular infections [46, 48, 49].

For methicillin-resistant $S$. aureus bacteremia, vancomycin has been the traditional drug of choice in the US and teicoplanin in Europe [39, 50]. However, this has been questioned recently in the setting of increasing vancomycin minimal inhibitory concentrations and associated treatment failures [51-54]. Other alternatives include dapotomycin, though safety and efficacy of daptomycin have not yet been established in children [55, 56]. Linezolid, clindamycin, trimethoprim-sulfamethoxazole, tigecycline, and telavancin should generally not be used as first line therapy for methicillin-resistant $S$. aureus bacteremia [39].

The duration of treatment for $S$. aureus bacteremia has been subject to debate; historically, adults were treated for four to six wk with parenteral antibiotics given risk of endovascular infection and or undetected metastatic focus of infection [57]. More recently, several adult retrospective studies and one meta-analysis have tried to evaluate this duration and have concluded that shorter courses of 14 days may be effective for uncomplicated $S$. aureus bacteremia, forming the basis of the current the infectious diseases society of America recommendation of at least 14 days of therapy [39, 58-60].

\subsection{Group A Streptococcus and toxic shock syndrome}

Both $S$. aureus and group A Streptococcus (GAS) are capable of producing superantigens, which can interact with antigen presenting cells and T-cells to cause massive cytokine release, leading to toxic shock syndrome, characterized by erythroderma, hypotension and organ failure. Diagnosis of staphylococcal toxic shock syndrome is primarily clinical, as blood cultures are rarely positive in this entity, whereas in streptococcal toxic shock syndrome, there is often an identifiable invasive infection, most notably bacteremia, skin or soft tissue infection (including necrotizing fasciitis), or community acquired pneumonia [61].

GAS remains extremely susceptible to beta-lactam antibiotics including penicillin, though in high inoculum infections, such as myositis, treatment failures can occur and mortality is high $[62,63]$. This has been attributed in part to the "Eagle effect," which is the observation that there are fewer replicating organisms at high bacterial concentrations, thus reducing the effectiveness of penicillin [62, 64]. Clindamycin is not affected by inoculum size, can inhibit protein synthesis, and has a longer post-antibiotic effect than penicillin. It has been shown to improve outcomes and should be used in cases of GAS sepsis, toxic shock, or severe invasive GAS infection [63, 65-67]. Prompt source control in cases of aggressive GAS infections such as necrotizing fasciitis, myositis, and empyema are paramount to survival $[62,63]$. Staphylococcal toxic shock is treated empirically as described above for $S$. aureus, however similar to streptococcal toxic shock syndrome the addition of clindamycin and source control should be considered as appropriate. In cases of suspected menstrual associated toxic shock syndrome, tampons should be promptly removed.

Intravenous immunoglobulin (IVIG) has been used as an adjunctive therapy in patients with toxic shock syndrome and may be of benefit in patients with streptococcal toxic shock syndrome despite overall lack of evidence supporting its use in sepsis in general $[66,68$, 69]. Mechanistically, it is thought that IVIG neutralizes superantigens and $\mathrm{M}$ proteins and exerts a generalized anti-inflammatory effect through Fc receptor interactions [61]. Adult studies and pediatric case reports have suggested that IVIG is of benefit in treating streptococcal toxic shock syndrome, though the one pediatric retrospective cohort study failed to detect any mortality benefit [69-74]. In staphylococcal toxic shock syndrome, data supporting use of IVIG are largely anecdotal and IVIG may have less affinity for staphylococcal superantigens $[61,75]$. The current American Academy of Pediatrics recommendation is to consider 
IVIG in cases refractory to several hours of aggressive therapy [76].

\subsection{Gram-negative bacteremia}

Sources of Gram-negative bacteremia include urinary tract infections, intra-abdominal infections or translocation of enteric Gram-negative bacteria, skin and soft tissue infections, and central line associated bloodstream infections, especially in immunocompromised hosts. Common organisms in both the developed and developing world include Klebsiella pneumonia, E. coli, Pseudomonas aeruginosa, Enterobacter species, non-typhoidal Salmonella, N. meningitidis, and $H$. influenzae. Of note in the developing world, invasive $H$. influenzae type B and S. typhi infections are more common [77-79]. Gram-negative antimicrobial resistance is an increasing problem worldwide [79].

The optimal empiric antimicrobial regimen for Gram-negative bacteremia is subject to some debate. Empiric regimens combining a beta-lactam with an aminoglycoside or fluoroquinolone are frequently utilized in suspected Gram-negative sepsis for several theoretical reasons. First, combination therapy increases the likelihood of administering at least one agent with activity against Gram-negative organisms, which have frequent intrinsic determinants of antibiotic resistance. Second, some Gram-negatives can acquire additional resistance elements while on therapy, notably $P$. aeruginosa and third, combinations of antibiotics may exert a synergistic effect. Several adult retrospective studies have suggested improved mortality with empiric combination therapy though several others have failed to show any survival benefit over appropriate monotherapy, including for Pseudomonas, though this remains controversial [80-91]. Current guidelines suggest that in patients with severe illness at high risk for mortality or multidrug resistant Gramnegative pathogens, empiric combination therapy with an anti-pseudomonal beta-lactam combined with a second agent from another class is recommended [27, 92-94]. In developing countries, empiric therapy should also cover $S$. typhi, which is increasingly resistant to ampicillin, chloramphenicol, and cotrimoxazole. Alternative therapies include fluoroquinolones, third generation cephalosporins, or azithromycin with empiric treatment decisions based on local susceptibility patterns and severity of illness [95].

Once the identity of the organism is known, monotherapy guided by reported sensitivities is adequate for most Gram-negative infections with the possible exception of pseudomonal infections, though this may prove difficult in cases of multidrug resistant Gram-negative infections, including extended spectrum beta-lactamase producing organisms, carbapenemase-resistant Enterobacteriaceae, and carbapenem-resistant Acinetobacter baumannii and $P$. aeruginosa, which are increasing in frequency in pediatric populations [86, 96-98]. Extended spectrum beta-lactamase producing organisms can be effectively treated with carbapenems and perhaps cefepime, piperacillin-tazobactam, and fluoroquinolones. Although pediatric data are limited, possible therapies for carbapenem-resistant organisms include continuous infusions of carbapenem combined with an aminoglycoside or fluoroquinolone (depending on the minimal inhibitory concentrations), polymixin, tigecycline, or fosfomycin [97]. Therapy should be continued for 7-14 days for central line associated bloodstream infections and urinary tract infection, with modifications to this duration made based on site of infection, infecting organism, and degree of source control $[93,99]$. Despite some evidence that shorter courses of therapy are effective for milder illness, severe $S$. typhi should be treated for at least 10-14 days [100]. Patients with severe illness from S. typhi and altered mental status may benefit from dexamethasone administration, which has been shown to reduce mortality in these high-risk patients [101]. Central lines should be removed if possible in cases of persistent bacteremia (i.e. greater than $72 \mathrm{hr}$ ) despite appropriate therapy, in cases of severe sepsis, suppurative thrombophlebitis, and considered in all cases $P$. aeruginosa bacteremia [93].

\subsection{Clostridium difficile}

C. difficile is an increasingly common pediatric pathogen among both community-dwelling and hospitalized children. Fortunately, severe disease is less common in children than in adults with only $2-17 \%$ of infected children developing severe complicated infection, depending on the definition used [102-105]. Initial therapy and therapy for first relapse of mild to moderate cases of $C$. difficile associated diarrhea is oral or intravenous metronidazole. All severe cases and second relapses should be treated with oral vancomycin [106-108]. Relapses occur in $12-24 \%$ of patients regardless of initial therapy [102, 103, 109]. Colectomy should be considered in patients with 
septic shock, refractory acidosis, and elevated white blood cell count $(>50,000)$ based on adult data suggesting worse outcomes if these risk factors are present [107]. Prevention of $C$. difficile depends on good infection control practices to limit spread and judicious use of antimicrobials. Probiotic during antimicrobial therapy have not been shown to reduce risk of $C$. difficile infection [107, 110].

\subsection{Anaerobic infections}

Anaerobes are implicated as pathogens in polymicrobial suppurative infections of many body sites, including brain or parameningeal abscesses via direct extension from the sinuses, other head and neck infections, intra-abdominal or pelvic abscesses or soft tissue infections. In the ICU, central nervous system (CNS) and intra-abdominal infections are among the most common foci of anaerobic infection. Therapy for infections of either site relies on prompt source control and initiation of appropriate antimicrobial therapy [111]. Therapy for CNS infections should include metronidazole to treat the anaerobic component in addition to vancomycin and a third or fourth generation cephalosporin. A carbapenem is an alternative therapy. Beta-lactamase inhibitors do not cross the blood brain barrier and are therefore not recommended for CNS infections. Therapy for intra-abdominal abscess should be guided by culture results but possible therapies include ticarcillin-clavulanate, piperacillintazobactam, a carbapenem, or a third or fourth generation cephalosporin combined with metronidazole, depending on assessed risk for Pseudomonas or other resistant organisms [112]. Lemierre's syndrome, or suppurative thrombophlebitis of the internal jugular vein generally caused by Fusobacterium necrophorum, is a rare anaerobic infection and is treated with metronidazole or clindamycin [113].

\subsection{Mycobacterium tuberculosis}

Only $1-3 \%$ of patients with $M$. tuberculosis require ICU admission. The most common reason for ICU admission is respiratory failure, other etiologies include multi-system organ failure and severe tuberculous meningitis [114, 115]. Rarely, miliary tuberculous can present as a sepsis-like syndrome, more commonly in patients with advanced Human immunodeficiency virus infection [116]. Initial therapy should include rifampin, isoniazid, ethambutol, and pyrazinamide in the US and Europe when no resistance is suspected. This regimen should be modified depending on local resistance patterns and the suspected source of the tuberculous infection $[117,118]$. In patients with tuberculous meningitis, steroids are recommended for both adults and children to reduce risk of death as well as disability [119, 120].

\section{Cardinal clinical syndromes}

\subsection{Meningitis}

Worldwide, H. influenzae, S. pneumoniae and $N$. meningitidis represent the three most common causes of bacterial meningitis in infants and children greater than three mo, but the epidemiology of these infections has been influenced by vaccine development for all three organisms with significant declines reported in H. influenza type B and S. pneumoniae [121-126]. In neurosurgical patients, including patients with ventriculoperitoneal shunts, S. aureus, coagulase-negative Staphylococcus, Gram-negative organisms, and Propionibacterium acnes are also important pathogens [127, 128].

Given the potential for severe neurologic sequelae, the clinician must maintain a high index of suspicion for bacterial meningitis, especially in patients with immunocompromise, cochlear implants, cerebrospinal fluid leak (CSF) leaks, and history of neurosurgery. Prompt evaluation with cerebral spinal fluid sampling for cell count, protein, glucose, and bacterial culture is paramount in confirming this diagnosis and guiding therapy, but should not delay initiation of appropriate empiric antimicrobials. Empiric therapy for most patients should include vancomycin, which covers resistant $S$. pneumoniae, and a third-generation cephalosporin with definitive therapy guided by culture results. In neurosurgical patients, empiric therapy should include vancomycin and an anti-pseudomonal beta-lactam or carbapenem [129]. In developing countries, initial therapy with ampicillin, penicillin or chloramphenicol are less expensive alternatives when third-generation cephalosporins are not available [130].

The duration of therapy depends on the organism identified; US guidelines recommend seven to fourteen days of therapy depending upon the pathogen identified [76, 129, 130] (Table 1). However, shorter durations of therapy of three to four $\mathrm{d}$ for $N$. menin- 
Table 1

Antibiotic recommendations for patients with bacterial meningitis

\begin{tabular}{lll}
\hline Organism & Antimicrobial & Duration of therapy \\
\hline $\begin{array}{l}\text { Streptoccocus pneumoniae } \\
\text { Susceptible to penicillin }\end{array}$ & Penicillin & $10-14$ days \\
$\begin{array}{l}\text { Susceptible to ceftriaxone/cefotaxime } \\
\text { Nonsusceptible to ceftriaxone/ cefotaxime }\end{array}$ & $\begin{array}{l}\text { Ceftriaxone/cefotaxime } \\
\text { Vancomycin and high-dose ceftriaxone/cefotaxime } \\
\text { Haemophilus influenzae }\end{array}$ & consider rifampin* \\
Beta-lactamase negative & Ampicillin & 10 days \\
Beta-lactamase positive & Ceftriaxone/cefotaxime & \\
Neisseria meningitidis & Penicillin, ampicillin, or ceftriaxone/cefotaxime** & 7 days \\
\hline
\end{tabular}

* Consider in cases of worsening clinical condition, failure to clear cerebrospinal fluid cultures, or organism has a high ceftriaxone/cefotaxime minimum inhibitory concentration $(>4 \mu \mathrm{g} / \mathrm{mL})$. ${ }^{* *}$ Consider ceftriaxone/cefotaxime in intermediate/non-susceptible isolates.

gitidis are not associated with worse outcomes and in epidemic situations in the developing world, a single dose of ceftriaxone or long acting chloramphenicol has been successfully used [131-133]. Shorter durations of therapy for $S$. pneumoniae and $H$. influenzae are less well studied, but durations as short as 5 days may be as effective as 10 days of therapy $[134,135]$. In neurosurgical patients, hardware should be removed and CSF sampled serially; choice and duration of antibiotic therapy is determined by the organism isolated and clearance of CSF cultures [129].

Much of the neurologic morbidity and mortality associated with bacterial meningitis is thought to be due to cerebral inflammation and edema, so corticosteroids have been investigated as adjunctive therapy to improve these outcomes. Though this therapy remains controversial, corticosteroids may be given before or concurrently with the first dose of antibiotics to decrease risk of hearing loss in $H$. influenzae type B meningitis and perhaps to reduce neurologic sequelae in pneumococcal meningitis, though more recent trials in the developing world have challenged these data [136-145].

\subsection{Community acquired pneumonia}

Empiric therapy for patients hospitalized in the ICU with severe community acquired pneumonia (CAP) or empyema should include a parenteral thirdgeneration cephalosporin (ceftriaxone or cefotaxime) and either vancomycin or clindamycin (depending on local susceptibility patterns for methicillin-resistant $S$. aureus) if there is a strong clinical suspicion for $S$. aureus or if effusion, abscess, or empyema is present [146]. This regimen covers the typical bacterial causes of pediatric CAP in developed countries, which include $S$. pneumoniae, $S$. aureus, occasionally group A Streptococcus, and rarely non-typeable $H$. influenzae. Currently the Infectious Diseases Society of America guidelines recommends addition of a macrolide antibiotic for treatment of CAP when Mycoplasma pneumoniae is suspected. However, there is a paucity of data to support or refute this practice [146-149].

For infections complicated by parapneumonic effusions or empyema, consideration should be given to chest tube placement with or without fibrinolysis or video assisted thoracoscopic surgery. Both of these interventions may decrease hospital length of stay, time to fever resolution, and need for additional drainage procedures compared to antibiotics alone [146, 150, 151]. Duration of therapy for uncomplicated pneumonia should be seven to ten days. Duration of therapy for complicated pneumonia depends on the clinical response to treatment and adequacy of drainage, but generally, two to four wk of therapy is sufficient [146].

In the developing world, $S$. pneumoniae and $H$. influenzae, including type B, S. aureus, and enteric Gram negatives are causes of pneumonia [152-154]. In Africa, non-typhoidal Salmonella is an additional common etiology of bacteremic pneumonia, especially among human immunodeficiency virus infected children $[155,156]$. Current World Health Organization guidelines recommend parenteral ampicillin or penicillin plus gentamicin for very severe pneumonia [157-159]. When available, ceftriaxone or cefotaxime can replace these [160]. A 10-day course of therapy is recommended, though shorter courses may be sufficient [157].

Legionella pneumophila has traditionally been considered an adult pathogen, but recent data suggests that this entity may occur more frequently but be under recognized in pediatric patients, especially 
immunocompromised patients who are at higher risk [161, 162]. Agents with activity against Legionella include macrolides and fluoroquinolones. Therapy should continue for 14 days, unless azithromycin is given in which case five to ten day of therapy is sufficient [163].

\subsection{Culture-negative sepsis}

Despite a meticulous search for the source of sepsis with bacterial cultures, clinical exam, and radiographic studies, no source can be identified in approximately half of patients with severe sepsis [5, 27, 164]. In such cases, after ruling out alternative diagnoses, the treating clinician must consider likely sources of infection based on the clinical scenario and prescribe antimicrobial therapy accordingly.

\section{Future directions}

The sources of bacterial sepsis are diverse, but in all cases outcome depends on attention to the central principles of rapid resuscitation with frequent reassessment, early appropriate antibiotics, aggressive source control, and rigorous diagnostic evaluation, all of which may be aided by a protocolized sepsis care pathway. In the future, bedside clinical diagnosis will be augmented by increasingly rapid, specific diagnostic techniques. Some clinically available lab tests have demonstrated promise for early recognition of bacterial infection or shock, including procalcitonin, lactate, C-reactive protein, and components of the complete blood count. However, the precise clinical markers, timing and population to screen for optimal test characteristics are unknown [165-168]. Successful pediatric sepsis risk-stratification strategies in a research setting include RNA expression profiling and novel serum biomarkers [169, 170]. Polymerase chain reaction and mass spectroscopy based techniques for rapid pathogen detection may replace or augment culture-based techniques in the coming years, allowing for more rapid initiation of effective antibiotics without exposing the patient to potentially ineffective or toxic empiric therapy [171]. Finally, variable clinical phenotypes are increasingly recognized in patients with severe sepsis, which may pave the way for genomic or proteomic based adjunctive therapies in management of septic shock [172].

\section{References}

[1] Liu L, Oza S, Hogan D, Perin J, Rudan I, Lawn JE, et al. Global, regional, and national causes of child mortality in 2000-13, with projections to inform post2015 priorities: An updated systematic analysis. Lancet 2014;S0140-6736(14)61698-6 (in press).

[2] Hartman ME, Linde-Zwirble WT, Angus DC, Watson RS Trends in the epidemiology of pediatric severe sepsis. Pediatr Crit Care Med 2013;14(7):686-93.

[3] Mangia CM, Kissoon N, Branchini OA, Andrade MC, Kopelman BI, Carcillo J. Bacterial sepsis in Brazilian children: A trend analysis from 1992 to 2006. PLoS One 2011;6(6):e14817.

[4] Odetola FO, Gebremariam A, Freed GL. Patient and hospital correlates of clinical outcomes and resource utilization in severe pediatric sepsis. Pediatrics 2007;119(3):487-94

[5] Watson RS, Carcillo JA, Linde-Zwirble WT, Clermont G Lidicker J, Angus DC. The epidemiology of severe sepsis in children in the United States. Am J Respir Crit Care Med 2003;167(5):695-701.

[6] Booy R, Habibi P, Nadel S, de Munter C, Britto J, Morrison A, et al. Meningococcal Research Group. Reduction in case fatality rate from meningococcal disease associated with improved healthcare delivery. Arch Dis Child 2001;85(5):386-90.

[7] Buysse CM, Raat H, Hazelzet JA, Hulst JM, Cransberg K, Hop WC, et al. Long-term health status in childhood survivors of meningococcal septic shock. Arch Pediatr Adolesc Med 2008;162(11):1036-41.

[8] Balamuth F, Weiss SL, Neuman MI, Scott H, Brady PW, Paul R, et al. Pediatric severe sepsis in U.S. children's hospitals. Pediatr Crit Care Med (in press).

[9] Berkley JA, Lowe BS, Mwangi I, Williams T, Bauni E, Mwarumba S, et al. Bacteremia among children admitted to a rural hospital in Kenya. N Engl J Med 2005;352(1): $39-47$.

[10] Aiken AM, Mturi N, Njuguna P, Mohammed S, Berkley JA Mwangi I, et al. Kilifi Bacteraemia Surveillance Group. Risk and causes of paediatric hospital-acquired bacteraemia in Kilifi District Hospital, Kenya: A prospective cohort study. Lancet 2011;378(9808):2021-7.

[11] Gaines NN, Patel B, Williams EA, Cruz AT. Etiologies of septic shock in a pediatric emergency department population. Pediatr Infect Dis J 2012;31(11):1203-5.

[12] Bateman SL, Seed PC. Procession to pediatric bacteremia and sepsis: Covert operations and failures in diplomacy. Pediatrics 2010;126(1):137-50.

[13] Jean-Baptiste E. Cellular mechanisms in sepsis. J Intensive Care Med 2007;22(2):63-72.

[14] Legrand M, Klijn E, Payen D, Ince C. The response of the host microcirculation to bacterial sepsis: Does the pathogen matter? J Mol Med (Berl) 2010;88(2):127-33.

[15] Duran-Bedolla J, Montes de Oca-Sandoval MA, SaldañaNavor V, Villalobos-Silva JA, Rodriguez MC, et al. Sepsis, mitochondrial failure and multiple organ dysfunction. Clin Invest Med 2014;37(2):E58-69.

[16] Brierley J, Carcillo JA, Choong K, Cornell T, Decaen A, Deymann A, et al. Clinical practice parameters for hemodynamic support of pediatric and neonatal septic shock: 2007 update from the American College of Critical Care Medicine. Crit Care Med 2009;37(2):666-88. 
[17] Rivers E, Nguyen B, Havstad S, Ressler J, Muzzin A, Knoblich B, et al. Early Goal-Directed Therapy Collaborative Group. Early goal-directed therapy in the treatment of severe sepsis and septic shock. N Engl J Med 2001;345(19):1368-77.

[18] Jones AE, Shapiro NI, Trzeciak S, Arnold RC, Claremont HA, Kline JA; Emergency Medicine Shock Research Network (EMShockNet) Investigators. Lactate clearance vs central venous oxygen saturation as goals of early sepsis therapy: A randomized clinical trial. JAMA 2010;303(8):739-46.

[19] Puskarich MA, Trzeciak S, Shapiro NI, Arnold RC, Heffner AC, Kline JA, et al. Emergency Medicine Shock Research Network (EMSHOCKNET). Prognostic value and agreement of achieving lactate clearance or central venous oxygen saturation goals during early sepsis resuscitation. Acad Emerg Med 2012;19(3):252-8.

[20] ProCESS Investigators, Yealy DM, Kellum JA, Huang DT, Barnato AE, Weissfeld LA, Pike F, et al. A randomized trial of protocol-based care for early septic shock. N Engl J Med 2014;370(18):1683-93

[21] Carcillo JA, Davis AL, Zaritsky A. Role of early fluid resuscitation in pediatric septic shock. JAMA 1991;266(9):1242-5.

[22] Maitland K, Kiguli S, Opoka RO, Engoru C, OlupotOlupot P, Akech SO, et al. FEAST Trial Group. Mortality after fluid bolus in African children with severe infection. $\mathrm{N}$ Engl J Med 2011;364(26):2483-95.

[23] Scott H, Melendez E, Cruz AT; American Academy of Pediatrics, Section on Emergency Medicine, Septic Shock Collaborative. Mortality after fluid bolus in African children with sepsis. N Engl J Med 2011;365(14):1350-1.

[24] Joyner BL Jr, Boyd JM, Kocis KC. Mortality after fluid bolus in African children with sepsis. N Engl J Med 2011;365(14):1349-50.

[25] Kissoon N, Carcillo JA. Global Sepsis Initiative of the World Federation of Pediatric Intensive and Critical Care Societies. Mortality after fluid bolus in African children with sepsis. N Engl J Med 2011;365(14):1350.

[26] Ceneviva G, Paschall JA, Maffei F, Carcillo JA. Hemodynamic support in fluid-refractory pediatric septic shock. Pediatrics 1998;102(2):e19.

[27] Dellinger RP, Levy MM, Rhodes A, Annane D, Gerlach H, Opal SM, et al. Surviving Sepsis Campaign Guidelines Committee including The Pediatric Subgroup. Surviving Sepsis Campaign: International guidelines for management of severe sepsis and septic shock, 2012. Intensive Care Med 2013;39(2):165-228

[28] Kumar A, Roberts D, Wood KE, Light B, Parrillo JE, Sharma $S$, et al. Duration of hypotension before initiation of effective antimicrobial therapy is the critical determinant of survival in human septic shock. Crit Care Med 2006;34(6):1589-96.

[29] Ferrer R, Artigas A, Suarez D, Palencia E, Levy MM, Arenzana A, et al. Edusepsis Study Group. Effectiveness of treatments for severe sepsis: A prospective, multicenter, observational study. Am J Respir Crit Care Med 2009;180(9):861-6.

[30] Gaieski DF, Mikkelsen ME, Band RA, Pines JM, Massone $\mathrm{R}$, Furia FF, et al. Impact of time to antibiotics on survival in patients with severe sepsis or septic shock in whom early goal-directed therapy was initiated in the emergency department. Crit Care Med 2010;38(4):1045-53.
[31] Ferrer R, Martin-Loeches I, Phillips G, Osborn TM, Townsend S, Dellinger RP, et al. Empiric antibiotic treatment reduces mortality in severe sepsis and septic shock from the first hour: Results from a guidelinebased performance improvement program. Crit Care Med 2014;42(8):1749-55

[32] Weiss SL, Fitzgerald JC, Balamuth F, Alpern ER, Lavelle J, Chilutti M, et al. Delayed antimicrobial therapy increases mortality and organ dysfunction duration in pediatric sepsis. Crit Care Med 2014 (in press)

[33] Puskarich MA, Trzeciak S, Shapiro NI, Arnold RC, Horton JM, Studnek JR, et al. Emergency Medicine Shock Research Network (EMSHOCKNET). Association between timing of antibiotic administration and mortality from septic shock in patients treated with a quantitative resuscitation protocol. Crit Care Med 2011;39(9):2066-71.

[34] van den Bosch CM, Hulscher ME, Natsch S, Gyssens IC, Prins JM, Geerlings SE. Dutch Sepsis QI expert panel. Development of quality indicators for antimicrobial treatment in adults with sepsis. BMC Infect Dis 2014;14:345.

[35] Cruz AT, Perry AM, Williams EA, Graf JM, Wuestner ER, Patel B. Implementation of goal-directed therapy for children with suspected sepsis in the emergency department. Pediatrics 2011;127(3):e758-66.

[36] Larsen GY, Mecham N, Greenberg R. An emergency department septic shock protocol and care guideline for children initiated at triage. Pediatrics 2011;127(6):e1585-92.

[37] Paul R, Neuman MI, Monuteaux MC, Melendez E. Adherence to PALS sepsis guidelines and hospital length of stay. Pediatrics 2012;130(2):e273-80.

[38] Paul R, Melendez E, Stack A, Capraro A, Monuteaux M, Neuman MI. Improving adherence to PALS septic shock guidelines. Pediatrics 2014;133(5):e1358-66.

[39] Liu C, Bayer A, Cosgrove SE, Daum RS, Fridkin SK, Gorwitz RJ, et al. Infectious Diseases Society of America. Clinical practice guidelines by the infectious diseases society of America for the treatment of methicillin-resistant Staphylococcus aureus infections in adults and children. Clin Infect Dis 2011;52(3):e18-55.

[40] Kaplan SL, Hulten KG, Gonzalez BE, Hammerman WA, Lamberth L, Versalovic J, et al. Three-year surveillance of community-acquired Staphylococcus aureus infections in children. Clin Infect Dis 2005;40(12):1785-91.

[41] Vanderkooi OG, Gregson DB, Kellner JD, Laupland KB. Staphylococcus aureus bloodstream infections in children: A population-based assessment. Paediatr Child Health 2011;16(5):276-80.

[42] Keynan Y, Rubinstein E. Staphylococcus aureus bacteremia, risk factors, complications, and management. Crit Care Clin 2013;29(3):547-62.

[43] Valente AM, Jain R, Scheurer M, Fowler VG Jr, Corey GR, Bengur AR, et al. Frequency of infective endocarditis among infants and children with Staphylococcus aureus bacteremia. Pediatrics 2005;115(1):e15-9.

[44] Kim SH, Kim KH, Kim HB, Kim NJ, Kim EC, Oh MD, et al. Outcome of vancomycin treatment in patients with methicillin-susceptible Staphylococcus aureus bacteremia. Antimicrob Agents Chemother 2008;52(1):192-7.

[45] Lee S, Choe PG, Song KH, Park SW, Kim HB, Kim NJ, et al. Is cefazolin inferior to nafcillin for treatment of methicillinsusceptible Staphylococcus aureus bacteremia? Antimicrob Agents Chemother 2011;55(11):5122-6. 
[46] Paul M, Zemer-Wassercug N, Talker O, Lishtzinsky Y, Lev B, Samra Z, et al. Are all beta-lactams similarly effective in the treatment of methicillin-sensitive Staphylococcus aureus bacteraemia? Clin Microbiol Infect 2011;17(10): 1581-6.

[47] Schweizer ML, Furuno JP, Harris AD, Johnson JK, Shardell MD, McGregor JC, et al. Comparative effectiveness of nafcillin or cefazolin versus vancomycin in methicillinsusceptible Staphylococcus aureus bacteremia. BMC Infect Dis 2011;11:279.

[48] Wieland BW, Marcantoni JR, Bommarito KM, Warren DK, Marschall J. A retrospective comparison of ceftriaxone versus oxacillin for osteoarticular infections due to methicillin-susceptible Staphylococcus aureus. Clin Infect Dis 2012;54(5):585-90

[49] Winans SA, Luce AM, Hasbun R. Outpatient parenteral antimicrobial therapy for the treatment of methicillinsusceptible Staphylococcus aureus: A comparison of cefazolin and ceftriaxone. Infection 2013;41(4):769-74

[50] Yoon YK, Park DW, Sohn JW, Kim HY, Kim YS, Lee $\mathrm{CS}$, et al. Multicenter prospective observational study of the comparative efficacy and safety of vancomycin versus teicoplanin in patients with health care-associated methicillin-resistant Staphylococcus aureus bacteremia. ntimicrob Agents Chemother 2014;58(1):317-24

[51] Hidayat LK, Hsu DI, Quist R, Shriner KA, WongBeringer A. High-dose vancomycin therapy for methicillinresistant Staphylococcus aureus infections: Efficacy and toxicity. Arch Intern Med 2006;166(19):2138-44.

[52] Lodise TP, Graves J, Evans A, Graffunder E, Helmecke M, Lomaestro BM, et al. Relationship between vancomycin MIC and failure among patients with methicillin-resistant Staphylococcus aureus bacteremia treated with vancomycin. Antimicrob Agents Chemother 2008;52(9): 3315-20.

[53] Soriano A, Marco F, Martínez JA, Pisos E, Almela M, Dimova VP, et al. Influence of vancomycin minimum inhibitory concentration on the treatment of methicillinresistant Staphylococcus aureus bacteremia. Clin nfect Dis 2008;46(2):193-200

[54] Lodise TP, Drusano GL, Zasowski E, Dihmess A Lazariu V, Cosler L, et al. Vancomycin exposure in patients with methicillin-resistant Staphylococcus aureus bloodstream infections: How much is enough? Clin Infect Dis 2014;59(5):666-75.

[55] Fowler VG Jr, Boucher HW, Corey GR, Abrutyn E, Karchmer AW, Rupp ME, et al. S. aureus Endocarditis and Bacteremia Study Group. Daptomycin versus standard therapy for bacteremia and endocarditis caused by Staphylococcus aureus. N Engl J Med 2006;355(7):653-65.

[56] Moore CL, Osaki-Kiyan P, Haque NZ, Perri MB, Donabedian S, Zervos MJ. Daptomycin versus vancomycin for bloodstream infections due to methicillin-resistant Staphylococcus aureus with a high vancomycin minimum inhibitory concentration: A case-control study. Clin Infect Dis 2012;54(1):51-8.

[57] Cosgrove SE, Fowler VG Jr. Management of methicillinresistant Staphylococcus aureus bacteremia. Clin Infect Dis 2008;46(Suppl 5):S386-93.

[58] Jernigan JA, Farr BM. Short-course therapy of catheterrelated Staphylococcus aureus bacteremia: A meta-analysis. Ann Intern Med 1993;119(4):304-11.
[59] Raad II, Sabbagh MF. Optimal duration of therapy for catheter-related Staphylococcus aureus bacteremia: A study of 55 cases and review. Clin Infect Dis 1992;14(1):75-82.

[60] Zeylemaker MM, Jaspers CA, van Kraaij MG, Visser MR, Hoepelman IM. Long-term infectious complications and their relation to treatment duration in catheter-related Staphylococcus aureus bacteremia. Eur J Clin Microbiol Infect Dis 2001;20(6):380-4.

[61] Low DE. Toxic shock syndrome: Major advances in pathogenesis, but not treatment. Crit Care Clin 2013;29(3): 651-75.

[62] EAGLE H. Experimental approach to the problem of treatment failure with penicillin. I. Group A streptococcal infection in mice. Am J Med 1952;13(4):389-99.

[63] Stevens DL, Gibbons AE, Bergstrom R, Winn V. The Eagle effect revisited: Efficacy of clindamycin, erythromycin, and penicillin in the treatment of streptococcal myositis. J Infect Dis 1988;158(1):23-8.

[64] Stevens DL, Yan S, Bryant AE. Penicillin-binding protein expression at different growth stages determines penicillin efficacy in vitro and in vivo: An explanation for the inoculum effect. J Infect Dis 1993;167(6):1401-5.

[65] Steer AC, Lamagni T, Curtis N, Carapetis JR. Invasive group a streptococcal disease: Epidemiology, pathogenesis and management. Drugs 2012;72(9):1213-27.

[66] Linnér A, Darenberg J, Sjölin J, Henriques-Normark B, Norrby-Teglund A. Clinical efficacy of polyspecific intravenous immunoglobulin therapy in patients with streptococcal toxic shock syndrome: A comparative observational study. Clin Infect Dis 2014;59(6):851-7.

[67] Carapetis JR, Jacoby P, Carville K, Ang SJ, Curtis N, Andrews R. Effectiveness of clindamycin and intravenous immunoglobulin, and risk of disease in contacts, in invasive group a streptococcal infections. Clin Infect Dis 2014;59(3):358-65

[68] Alejandria MM, Lansang MA, Dans LF, Mantaring JB 3rd. Intravenous immunoglobulin for treating sepsis, severe sepsis and septic shock. Cochrane Database Syst Rev 2013;9:CD001090.

[69] Darenberg J, Ihendyane N, Sjölin J, Aufwerber E, Haidl S, Follin P, et al. StreptIg Study Group. Intravenous immunoglobulin $G$ therapy in streptococcal toxic shock syndrome: A European randomized, double-blind, placebocontrolled trial. Clin Infect Dis 2003;37(3):333-40.

[70] Cawley MJ, Briggs M, Haith LR Jr, Reilly KJ, Guilday $\mathrm{RE}$, Braxton GR, et al. Intravenous immunoglobulin as adjunctive treatment for streptococcal toxic shock syndrome associated with necrotizing fasciitis: Case report and review. Pharmacotherapy 1999;19(9): 1094-8.

[71] Burnett AM, Domachowske JB. Therapeutic considerations for children with invasive group a streptococcal infections: A case series report and review of the literature. Clin Pediatr (Phila) 2007;46(6):550-5

[72] Shah SS, Hall M, Srivastava R, Subramony A, Levin JE. Intravenous immunoglobulin in children with streptococcal toxic shock syndrome. Clin Infect Dis 2009;49(9):1369-76.

[73] Valiquette L, Low DE, McGeer AJ. Assessing the impact of intravenous immunoglobulin in the management of streptococcal toxic shock syndrome: A noble but difficult quest. Clin Infect Dis 2009;49(9):1377-9.

[74] Kaul R, McGeer A, Norrby-Teglund A, Kotb M, Schwartz B, O'Rourke K, et al. Intravenous immunoglobulin therapy for 
streptococcal toxic shock syndrome-a comparative observational study. The Canadian Streptococcal Study Group. Clin Infect Dis 1999;28(4): 800-7.

[75] Darenberg J, Söderquist B, Normark BH, NorrbyTeglund A. Differences in potency of intravenous polyspecific immunoglobulin $\mathrm{G}$ against streptococcal and staphylococcal superantigens: Implications for therapy of toxic shock syndrome. Clin Infect Dis 2004;38(6): 836-42.

[76] Pickering LK, Baker CJ, Kimberlin DW, Long SS, editors. Red Book 2012 Report of the Committee on Infectious Diseases. 29th ed. Elk Grove Village (IL): American Academy of Pediatrics; 2012

[77] Reddy EA, Shaw AV, Crump JA. Community-acquired bloodstream infections in Africa: A systematic review and meta-analysis. Lancet Infect Dis 2010;10(6):417-32

[78] Tiwari DK, Golia S, Sangeetha KT, Vasudha CL. A study on the bacteriological profile and antibiogram of bacteremia in children below 10 years in a tertiary care hospital in Bangalore, India. J Clin Diagn Res 2013;7(12):2732-5.

[79] Leopold SJ, van Leth F, Tarekegn H, Schultsz C. Antimicrobial drug resistance among clinically relevant bacterial isolates in sub-Saharan Africa: A systematic review. J Antimicrob Chemother 2014;69(9):2337-53.

[80] Al-Hasan MN, Wilson JW, Lahr BD, Thomsen KM, Eckel-Passow JE, Vetter EA, et al. Beta-lactam and fluoroquinolone combination antibiotic therapy for bacteremia caused by gram-negative bacilli. Antimicrob Agents Chemother 2009;53(4):1386-94.

[81] Kumar A, Safdar N, Kethireddy S, Chateau D. A survival benefit of combination antibiotic therapy for serious infections associated with sepsis and septic shock is contingent only on the risk of death: A meta-analytic/meta-regression study. Crit Care Med 2010;38(8):1651-64.

[82] Kumar A, Zarychanski R, Light B, Parrillo J, Maki D, Simon D, et al. Cooperative Antimicrobial Therapy of Septic Shock (CATSS) Database Research Group. Early combination antibiotic therapy yields improved survival compared with monotherapy in septic shock: A propensity-matched analysis. Crit Care Med 2010;38(9):1773-85.

[83] Micek ST, Welch EC, Khan J, Pervez M, Doherty JA, Reichley RM, et al. Empiric combination antibiotic therapy is associated with improved outcome against sepsis due to Gram-negative bacteria: A retrospective analysis. Antimicrob Agents Chemother 2010;54(5):1742-8.

[84] Safdar N, Handelsman J, Maki DG. Does combination antimicrobial therapy reduce mortality in Gramnegative bacteraemia? A meta-analysis. Lancet Infect Dis 2004;4(8):519-27.

[85] Marcus R, Paul M, Elphick H, Leibovici L. Clinical implications of $\beta$-lactam-aminoglycoside synergism: Systematic review of randomised trials. Int $\mathrm{J}$ Antimicrob Agents 2011;37(6):491-503.

[86] Paul M, Lador A, Grozinsky-Glasberg S, Leibovici L. Beta lactam antibiotic monotherapy versus beta lactamaminoglycoside antibiotic combination therapy for sepsis. Cochrane Database Syst Rev 2014;1:CD003344.

[87] Brunkhorst FM, Oppert M, Marx G, Bloos F, Ludewig K, Putensen C, et al.; German Study Group Competence Network Sepsis (SepNet). Effect of empirical treatment with moxifloxacin and meropenem vs meropenem on sepsisrelated organ dysfunction in patients with severe sepsis: A randomized trial. JAMA 2012;307(22):2390-9.
[88] Kim YJ, Jun YH, Kim YR, Park KG, Park YJ, Kang JY, et al. Risk factors for mortality in patients with $P$. aeruginosa bacteremia; retrospective study of impact of combination antimicrobial therapy. BMC Infect Dis 2014;14:161.

[89] Bliziotis IA, Petrosillo N, Michalopoulos A, Samonis G, Falagas ME. Impact of definitive therapy with beta-lactam monotherapy or combination with an aminoglycoside or a quinolone for Pseudomonas aeruginosa bacteremia. PLoS One 2011;6(10):e26470.

[90] Bowers DR, Liew YX, Lye DC, Kwa AL, Hsu LY, Tam VH. Outcomes of appropriate empiric combination versus monotherapy for Pseudomonas aeruginosa bacteremia. Antimicrob Agents Chemother 2013;57(3):1270-4.

[91] Peña C, Suarez C, Ocampo-Sosa A, Murillas J, Almirante B, Pomar V, et al. Spanish Network for Research in Infectious Diseases (REIPI). Effect of adequate single-drug vs combination antimicrobial therapy on mortality in Pseudomonas aeruginosa bloodstream infections: A post Hoc analysis of a prospective cohort. Clin Infect Dis 2013;57(2):208-16.

[92] Freifeld AG, Bow EJ, Sepkowitz KA, Boeckh MJ, Ito JI, Mullen CA, et al. Infectious Diseases Society of America. Clinical practice guideline for the use of antimicrobial agents in neutropenic patients with cancer: 2010 update by the Infectious Diseases Society of America. Clin Infect Dis 2011;52(4):e56-93.

[93] Mermel LA, Allon M, Bouza E, Craven DE, Flynn P, O'Grady NP, et al. Clinical practice guidelines for the diagnosis and management of intravascular catheter-related infection: 2009 Update by the Infectious Diseases Society of America. Clin Infect Dis 2009;49(1):1-45.

[94] Sick AC, Tschudin-Sutter S, Turnbull AE, Weissman SJ, Tamma PD. Empiric combination therapy for gram-negative bacteremia. Pediatrics 2014;133(5):e1148-55.

[95] Vala S, Shah U, Ahmad SA, Scolnik D, Glatstein M. Resistance patterns of typhoid fever in children: A longitudinal community-based study. Am J Ther 2014 (in press).

[96] Tamma PD, Turnbull AE, Harris AD, Milstone AM, Hsu AJ, Cosgrove SE. Less is more: Combination antibiotic therapy for the treatment of gram-negative bacteremia in pediatric patients. JAMA Pediatr 2013;167(10):903-10.

[97] Hsu AJ, Tamma PD. Treatment of multidrug-resistant Gram-negative infections in children. Clin Infect Dis 2014;58(10):1439-48.

[98] Logan LK. Carbapenem-resistant enterobacteriaceae: An emerging problem in children. Clin Infect Dis 2012;55(6):852-9.

[99] Hooton TM, Bradley SF, Cardenas DD, Colgan R, Geerlings SE, Rice JC, et al. Infectious Diseases Society of America. Diagnosis, prevention, and treatment of catheter-associated urinary tract infection in adults: 2009 International Clinical Practice Guidelines from the Infectious Diseases Society of America. Clin Infect Dis 2010;50(5):625-63.

[100] Acharya G, Butler T, Ho M, Sharma PR, Tiwari M, Adhikari RK, et al. Treatment of typhoid fever: Randomized trial of a three-day course of ceftriaxone versus a fourteen-day course of chloramphenicol. Am J Trop Med Hyg 1995;52(2):162-5.

[101] Hoffman SL, Punjabi NH, Kumala S, Moechtar MA Pulungsih SP, Rivai AR, et al. Reduction of mortality in chloramphenicol-treated severe typhoid fever by high-dose dexamethasone. N Engl J Med 1984;310(2):82-8.

[102] Khanna S, Baddour LM, Huskins WC, Kammer PP Faubion WA, Zinsmeister AR, et al. The epidemiology of 
Clostridium difficile infection in children: A populationbased study. Clin Infect Dis 2013;56(10):1401-6.

[103] Kim J, Shaklee JF, Smathers S, Prasad P, Asti L, Zoltanski $\mathrm{J}$, et al. Risk factors and outcomes associated with severe Clostridium difficile infection in children. Pediatr Infect Dis J 2012;31(2):134-8.

[104] Schwartz KL, Darwish I, Richardson SE, Mulvey MR, Thampi N. Severe clinical outcome is uncommon in Clostridium difficile infection in children: A retrospective cohort study. BMC Pediatr 2014;14:28.

[105] Tschudin-Sutter S, Tamma PD, Milstone AM, Perl TM. The prediction of complicated Clostridium difficile infections in children. Infect Control Hosp Epidemiol 2014;35(7): 901-3.

[106] Zar FA, Bakkanagari SR, Moorthi KM, Davis MB. A comparison of vancomycin and metronidazole for the treatment of Clostridium difficile-associated diarrhea, stratified by disease severity. Clin Infect Dis 2007;45(3): 302-7.

[107] Cohen SH, Gerding DN, Johnson S, Kelly CP, Loo VG, McDonald LC, et al.; Society for Healthcare Epidemiology of America; Infectious Diseases Society of America. Clinical practice guidelines for Clostridium difficile infection in adults: 2010 update by the society for healthcare epidemiology of America (SHEA) and the infectious diseases society of America (IDSA). Infect Control Hosp Epidemiol 2010;31(5):431-55

[108] Tamma PD, Sandora TJ. Clostridium difficile infection in children: Current state and unanswered questions. J Pediatric Infect Dis Soc 2012;1(3):230-243.

[109] Tschudin-Sutter S, Tamma PD, Milstone AM, Perl TM. Predictors of first recurrence of Clostridium difficile infections in children. Pediatr Infect Dis J 2014;33(4):414-6.

[110] Goldenberg JZ, Ma SS, Saxton JD, Martzen MR, Vandvik $\mathrm{PO}$, Thorlund $\mathrm{K}$, et al. Probiotics for the prevention of Clostridium difficile-associated diarrhea in adults and children. Cochrane Database Syst Rev 20131;5:CD006095.

[111] Brook I. Anaerobic infections in children. Microbes Infect 2002;4(12):1271-80.

[112] Solomkin JS, Mazuski JE, Bradley JS, Rodvold KA, Goldstein EJ, Baron EJ, et al. Diagnosis and management of complicated intra-abdominal infection in adults and children: Guidelines by the Surgical Infection Society and the Infectious Diseases Society of America. Clin Infect Dis 2010;50(2):133-64.

[113] Karkos PD, Asrani S, Karkos CD, Leong SC, Theochari EG, Alexopoulou TD, et al. Lemierre's syndrome: A systematic review. Laryngoscope 2009;119(8):1552-9.

[114] Hagan G, Nathani N. Clinical review: Tuberculosis on the intensive care unit. Crit Care 2013;17(5):240.

[115] Heyns L, Gie RP, Kling S, Samaai P, Schaaf HS, Beyers N. Management of children with tuberculosis admitted to a pediatric intensive care unit. Pediatr Infect Dis J 1998;17(5):403-7.

[116] Barber TW, Craven DE, McCabe WR. Bacteremia due to Mycobacterium tuberculosis in patients with human immunodeficiency virus infection. A report of 9 cases and a review of the literature. Medicine (Baltimore) 1990;69(6): 375-83.

[117] Migliori GB, Zellweger JP, Abubakar I, Ibraim E, Caminero JA, De Vries G, et al. European union standards for tuberculosis care. Eur Respir J 2012;39(4):807-19.
[118] Guidance for National Tuberculosis Programmes on the Management of Tuberculosis in Children. 2nd ed. Geneva World Health Organization; 2014

[119] Prasad K, Singh MB. Corticosteroids for managing tuberculous meningitis. Cochrane Database Syst Rev 2008;(1):CD002244.

[120] Thwaites GE, Nguyen DB, Nguyen HD, Hoang TQ, Do TT, Nguyen TC, et al. Dexamethasone for the treatment of tuberculous meningitis in adolescents and adults. N Engl J Med 2004;351(17):1741-51

[121] Martin M, Casellas JM, Madhi SA, Urquhart TJ, Delport $\mathrm{SD}$, Ferrero F, et al. Impact of Haemophilus influenzae type $\mathrm{b}$ conjugate vaccine in South Africa and Argentina. Pediatr Infect Dis J 2004;23(9):842-7.

[122] Ladhani S, Slack MP, Heath PT, von Gottberg A, Chandra M, Ramsay ME. European Union Invasive Bacterial Infection Surveillance participants. Invasive Haemophilus influenzae disease, Europe, 1996-2006. Emerg Infect Dis 2010;16(3):455-63

[123] Hsu HE, Shutt KA, Moore MR, Beall BW, Bennett NM, Craig AS, et al. Effect of pneumococcal conjugate vaccine on pneumococcal meningitis. N Engl J Med 2009;360(3):244-56

[124] Techasaensiri C, Messina AF, Katz K, Ahmad N, Huang R McCracken GH Jr. Epidemiology and evolution of invasive pneumococcal disease caused by multidrug resistant serotypes of 19A in the 8 years after implementation of pneumococcal conjugate vaccine immunization in Dallas, Texas. Pediatr Infect Dis J 2010;29(4): 294-300.

[125] Black S, Shinefield H, Baxter R, Austrian R, Bracken L, Hansen J, et al. Postlicensure surveillance for pneumococcal invasive disease after use of heptavalent pneumococcal conjugate vaccine in Northern California Kaiser Permanente. Pediatr Infect Dis J 2004;23(6):485-9.

[126] Centers for Disease Control and Prevention (CDC). Invasive pneumococcal disease in children 5 years after conjugate vaccine introduction-eight states, 1998-2005. MMWR Morb Mortal Wkly Rep 2008;57(6):144-8.

[127] McGirt MJ, Zaas A, Fuchs HE, George TM, Kaye K, Sexton DJ. Risk factors for pediatric ventriculoperitoneal shunt infection and predictors of infectious pathogens. Clin Infect Dis 2003;36(7):858-62.

[128] Stevens NT, Greene CM, O'Gara JP, Bayston R, Sattar MT, Farrell M, et al. Ventriculoperitoneal shunt-related infections caused by Staphylococcus epidermidis: Pathogenesis and implications for treatment. Br $\mathbf{J}$ Neurosurg 2012;26(6):792-7.

[129] Tunkel AR, Hartman BJ, Kaplan SL, Kaufman BA, Roos KL, Scheld WM, et al. Practice guidelines for the management of bacterial meningitis. Clin Infect Dis 2004;39(9):1267-84

[130] World Health Organization. Control of epidemic meningococcal disease. WHO practical guidelines. 2nd ed. World Health Organization; 1998.

[131] Ellis-Pegler R, Galler L, Roberts S, Thomas M, Woodhouse A. Three days of intravenous benzyl penicillin treatment of meningococcal disease in adults. Clin Infect Dis 2003;37(5):658-62.

[132] Nathan N, Borel T, Djibo A, Evans D, Djibo S, Corty JF, et al. Ceftriaxone as effective as long-acting chlorampheni$\mathrm{col}$ in short-course treatment of meningococcal meningitis 
during epidemics: A randomised non-inferiority study. Lancet 2005;366(9482):308-13.

[133] Viladrich PF, Pallares R, Ariza J, Rufi G, Gudiol F. Four days of penicilin therapy for meningococcal meningitis. Arch Intern Med 1986;146(12):2380-2.

[134] Molyneux E, Nizami SQ, Saha S, Huu KT, Azam M, Bhutta ZA, et al. CSF 5 Study Group. 5 versus 10 days of treatment with ceftriaxone for bacterial meningitis in children: A double-blind randomised equivalence study. Lancet 2011;377(9780):1837-45.

[135] Karageorgopoulos DE, Valkimadi PE, Kapaskelis A, Rafailidis PI, Falagas ME. Short versus long duration of antibiotic therapy for bacterial meningitis: A meta-analysis of randomised controlled trials in children. Arch Dis Child 2009;94(8):607-14.

[136] Havens PL, Wendelberger KJ, Hoffman GM, Lee MB, Chusid MJ. Corticosteroids as adjunctive therapy in bacterial meningitis. A meta-analysis of clinical trials. Am J Dis Child 1989;143(9):1051-5.

[137] Geiman BJ, Smith AL. Dexamethasone and bacterial meningitis. A meta-analysis of randomized controlled trials. West J Med 1992;157(1):27-31.

[138] Lebel MH, Freij BJ, Syrogiannopoulos GA, Chrane DF, Hoyt MJ, Stewart SM, et al. Dexamethasone therapy for bacterial meningitis. Results of two double-blind, placebocontrolled trials. N Engl J Med 1988;319(15):964-71.

[139] McIntyre PB, Berkey CS, King SM, Schaad UB, Kilpi T, Kanra GY, et al. Dexamethasone as adjunctive therapy in bacterial meningitis. A meta-analysis of randomized clinical trials since 1988. JAMA 1997;278(11):925-31.

[140] Kanra GY, Ozen H, Seçmeer G, Ceyhan M, Ecevit Z, Belgin E. Beneficial effects of dexamethasone in children with pneumococcal meningitis. Pediatr Infect Dis J 1995;14(6):490-4.

[141] Girgis NI, Farid Z, Mikhail IA, Farrag I, Sultan Y, Kilpatrick ME. Dexamethasone treatment for bacterial meningitis in children and adults. Pediatr Infect Dis J 1989;8(12):848-51.

[142] Arditi M, Mason EO Jr, Bradley JS, Tan TQ, Barson WJ, Schutze GE, et al. Three-year multicenter surveillance of pneumococcal meningitis in children: Clinical characteristics, and outcome related to penicillin susceptibility and dexamethasone use. Pediatrics 1998;102(5):1087-97.

[143] Molyneux EM, Walsh AL, Forsyth H, Tembo M, Mwenechanya J, Kayira K, et al. Dexamethasone treatment in childhood bacterial meningitis in Malawi: A randomised controlled trial. Lancet 2002;360(9328):211-8.

[144] Peltola H, Roine I, Fernández J, Zavala I, Ayala SG, Mata AG, et al. Adjuvant glycerol and/or dexamethasone to improve the outcomes of childhood bacterial meningitis: A prospective, randomized, double-blind, placebo-controlled trial. Clin Infect Dis 2007;45(10):1277-86.

[145] Brouwer MC, McIntyre P, Prasad K, van de Beek D. Corticosteroids for acute bacterial meningitis. Cochrane Database Syst Rev 2013;6:CD004405.

[146] Bradley JS, Byington CL, Shah SS, Alverson B, Carter ER, Harrison C, et al. Pediatric Infectious Diseases Society and the Infectious Diseases Society of America. The management of community-acquired pneumonia in infants and children older than 3 months of age: Clinical practice guidelines by the Pediatric Infectious Diseases Society and the Infectious Diseases Society of America. Clin Infect Dis 2011;53(7):e25-76.
[147] Meyer Sauteur PM, van Rossum AM, Vink C. Mycoplasma pneumoniae in children: Carriage, pathogenesis, and antibiotic resistance. Curr Opin Infect Dis 2014;27(3):220-7.

[148] Mulholland S, Gavranich JB, Gillies MB, Chang AB Antibiotics for community-acquired lower respiratory tract infections secondary to Mycoplasma pneumoniae in children. Cochrane Database Syst Rev 2012;9:CD004875.

[149] Biondi E, McCulloh R, Alverson B, Klein A, Dixon A. Treatment of mycoplasma pneumonia: A systematic review. Pediatrics 2014;133(6):1081-90.

[150] Kelly MM, Shadman KA, Edmonson MB. Treatment trends and outcomes in US hospital stays of children with empyema. Pediatr Infect Dis J 2014;33(5):431-6.

[151] Shah SS, Hall M, Newland JG, Brogan TV, Farris RW, Williams DJ, et al. Comparative effectiveness of pleural drainage procedures for the treatment of complicated pneumonia in childhood. J Hosp Med 2011;6(5):256-63.

[152] Goyet S, Vlieghe E, Kumar V, Newell S, Moore CE, Bousfield R, et al. Etiologies and resistance profiles of bacterial community-acquired pneumonia in Cambodian and neighboring countries' health care settings: A systematic review (1995 to 2012). PLoS One 2014;9(3):e89637.

[153] Zar HJ, Madhi SA, Aston SJ, Gordon SB. Pneumonia in low and middle income countries: Progress and challenges. Thorax 2013;68(11):1052-6.

[154] Howie SR, Morris GA, Tokarz R, Ebruke BE, Machuka EM, Ideh RC, et al. Etiology of severe childhood pneumonia in the gambia, West Africa, determined by conventional and molecular microbiological analyses of lung and pleural aspirate samples. Clin Infect Dis 2014;59(5):682-5.

[155] O'Dempsey TJ, McArdle TF, Lloyd-Evans N, Baldeh I, Laurence BE, Secka O, et al. Importance of enteric bacteria as a cause of pneumonia, meningitis and septicemia among children in a rural community in The Gambia, West Africa. Pediatr Infect Dis J 1994;13(2):122-8.

[156] Graham SM, English M. Non-typhoidal salmonellae: A management challenge for children with communityacquired invasive disease in tropical African countries. Lancet 2009;373(9659):267-9.

[157] Integrated Management of Childhood Illness (ICMI). Revised WHO classification and treatment of pneumonia in children at health facilities: Evidence summaries. Geneva: World Health Organization; 2014. Available at: http://www.who.int/maternal child adolescent/documents/child-pneumonia-treatment/en/. Accessed November 10, 2014.

[158] Asghar R, Banajeh S, Egas J, Hibberd P, Iqbal I, Katep-Bwalya M, et al. Severe Pneumonia Evaluation Antimicrobial Research Study Group. Chloramphenicol versus ampicillin plus gentamicin for community acquired very severe pneumonia among children aged 2-59 months in low resource settings: Multicentre randomised controlled trial (SPEAR study). BMJ 2008;336(7635):80-4.

[159] Duke T, Poka H, Dale F, Michael A, Mgone J, Wal T. Chloramphenicol versus benzylpenicillin and gentamicin for the treatment of severe pneumonia in children in Papua New Guinea: A randomised trial. Lancet 2002;359(9305): 474-80.

[160] Zar HJ, Jeena P, Argent A, Gie R, Madhi SA; Working Groups of the Paediatric Assembly of the South African Thoracic Society. Diagnosis and management of community-acquired pneumonia in childhood-South 
African Thoracic Society Guidelines. S Afr Med J 2005;95(12 Pt 2):977-81, 984-90.

[161] Greenberg D, Chiou CC, Famigilleti R, Lee TC, Yu VL. Problem pathogens: Paediatric legionellosis-implications for improved diagnosis. Lancet Infect Dis 2006;6(8):529-35

[162] Larru B, Gerber JS, Ota KV. Medical treatment failure and complete left pneumonectomy after Legionella pneumophila pneumonia in a bone marrow transplant recipient. Pediatr Infect Dis J 2012;31(9):979-81.

[163] Phin N, Parry-Ford F, Harrison T, Stagg HR, Zhang N, Kumar K, et al. Epidemiology and clinical management of Legionnaires' disease. Lancet Infect Dis 2014;14(10):10111021.

[164] Martin GS, Mannino DM, Eaton S, Moss M. The epidemiology of sepsis in the United States from 1979 through 2000. N Engl J Med 2003;348(16):1546-54.

[165] Lin SG, Hou TY, Huang DH, He SY, Lin YD, Zhang $\mathrm{LY}$, et al. Role of procalcitonin in the diagnosis of severe infection in pediatric patients with fever and neutropeniaa systemic review and meta-analysis. Pediatr Infect Dis J 2012;31(10):e182-8

[166] Andreola B, Bressan S, Callegaro S, Liverani A, Plebani M, $\mathrm{Da}$ Dalt L. Procalcitonin and C-reactive protein as diagnostic markers of severe bacterial infections in febrile infants and children in the emergency department. Pediatr Infect Dis J 2007;26(8):672-7.

[167] Vorwerk C, Manias K, Davies F, Coats TJ. Prediction of severe bacterial infection in children with an emergency department diagnosis of infection. Emerg Med J 2011;28(11):948-51.

[168] Scott HF, Donoghue AJ, Gaieski DF, Marchese RF, Mistry $\mathrm{RD}$. The utility of early lactate testing in undifferentiated pediatric systemic inflammatory response syndrome. Acad Emerg Med 2012;19(11):1276-80.

[169] Wong HR, Salisbury S, Xiao Q, Cvijanovich NZ, Hall M, Allen GL, et al. The pediatric sepsis biomarker risk model. Crit Care 2012;16(5):R174

[170] Wong HR, Weiss SL, Giuliano JS Jr, Wainwright MS, Cvijanovich NZ, Thomas NJ, et al. The temporal version of the pediatric sepsis biomarker risk model. PLoS One 2014;9(3):e92121.

[171] Kothari A, Morgan M, Haake DA. Emerging technologies for rapid identification of bloodstream pathogens. Clin Infect Dis 2014;59(2):272-8.

[172] Wong HR, Cvijanovich N, Lin R, Allen GL, Thomas NJ Willson DF, et al. Identification of pediatric septic shock subclasses based on genome-wide expression profiling. BMC Med 2009;7:34. 